\title{
A study of combined drug treatment and prevention of delirium tremens
}

\author{
Christos Vainas*, Pavlos Theofanidis, Christos Kakoulidis, Grigoria Skartsila, Eleni Karatasiou-Ntokatzi, Christos Siotis \\ From $1^{\text {st }}$ International Congress on Neurobiology and Clinical Psychopharmacology and European \\ Psychiatric Association Conference on Treatment Guidance \\ Thessaloniki, Greece. 19-22 November 2009
}

\section{Background}

The preventive treatment of emergency situations and complications caused by chronic alcoholism presents psychiatrists and physicians with a great challenge. Delirium tremens is a potentially fatal form of alcohol withdrawal (mortality rate 5\%-15\%) that usually occurs in patients with heavy and chronic alcohol abuse.

\section{Materials and methods}

Our research took place in a private psychiatric clinic (2005-2009) and focused on the effectiveness of a certain pharmacological combination administered to a sample of 37 patients, in an attempt to control the alcohol withdrawal syndrome. The pharmacological combination comprised 30mg-60mg Chlordiazepoxide hydrochloride, $300 \mathrm{mg}-500 \mathrm{mg}$ Triapride hydrochloride, 300mg-500mg Hydroxyzine hydrochloride, 576mg Clometiazol, 600mg1200mg Oxcarbazepine and B1+B2+B12 complex daily. Additionally, the patients received antidepressants and cardiovascular drugs.

\section{Results}

None of our sample patients developed any delirium tremens symptoms. The average duration of the drug combination administration was 11 days followed by a gradually decreasing dose until the maintenance dosage was reached.

\section{Conclusions}

When compared to other suggested drug treatments this method proved to be highly effective in delirium tremens prevention

Published: 22 April 2010

\section{doi:10.1186/1744-859X-9-S1-S227}

Cite this article as: Vainas et al:: A study of combined drug treatment and prevention of delirium tremens. Annals of General Psychiatry 2010 9(Suppl 1):S227.

\footnotetext{
"AGIA AIKATERINI" Private Psychiatric Clinic, Thessaloniki, Greece
}

Submit your next manuscript to BioMed Central and take full advantage of:

- Convenient online submission

- Thorough peer review

- No space constraints or color figure charges

- Immediate publication on acceptance

- Inclusion in PubMed, CAS, Scopus and Google Scholar

- Research which is freely available for redistribution

Submit your manuscript at www.biomedcentral.com/submit
C Biomed Central 